\title{
Reductionist and integrative research approaches to complex water security policy challenges
}

\begin{abstract}
This article reviews and contrasts two approaches that water security researchers employ to advance understanding of the complexity of water-society policy challenges. A prevailing reductionist approach seeks to represent uncertainty through calculable risk, links national GDP tightly to hydro-climatological causes, and underplays diversity and politics in society. When adopted uncritically, this approach limits policy-makers to interventions that may reproduce inequalities, and that are too rigid to deal with future changes in society and climate. A second, more integrative, approach is found to address a range of uncertainties, explicitly recognise diversity in society and the environment, incorporate water resources that are less-easily controlled, and consider adaptive approaches to move beyond conventional supply-side prescriptions. The resultant policy recommendations are diverse, inclusive, and more likely to reach the marginalised in society, though they often encounter policy-uptake obstacles. The article concludes by defining a route towards more effective water security research and policy, which stresses analysis that matches the state of knowledge possessed, an expanded research agenda, and explicitly addresses inequities.
\end{abstract}




\section{Complexity: the fault-line of water security research}

A 2012 review of water security research categroised it as either narrow and disciplinespecific, or broad and integrative (Cook and Bakker 2012). The authors demonstrated how the narrow framings facilitated uptake into policy, and convincingly argued that they would be usefully complemented by the broader framings, in order to ensure that "robust governance processes [serve] to mediate the trade-offs between different stakeholders, scales, and uses of water" (Cook and Bakker 2012: 98).

Four years and many peer-reviewed water security articles later, there is very little evidence of such blended water security research or policy. What may be observed instead is a drifting apart and entrenching, as in the recent water security debate in Science that posits environmental solutions against infrastructure solutions (Muller et al., 2015; Palmer et al., 2015). Others have noted that the concept of water security is 'popular but contested' (Pahl-Wostl et al., 2016), called for its reframing (Tarlock and Wouters, 2010), or labelled the contentions as a 'battleground of ideas' (Zeitoun et al., 2013). The dissonance is evident from the contradicting and growing number of definitions of water security shown in Table 1.

Table 1. Contrasting definitions of water security. For more comprehensive reviews see Cook and Bakker (2012) and van Beek and Lincklaen Arriens (2014).

\begin{tabular}{|c|c|c|}
\hline Notes & Definition of water security & Source \\
\hline $\begin{array}{l}\text { The Hague Ministerial } \\
\text { Declaration on Water Security } \\
\text { in the } 21^{\text {st }} \text { Century had social } \\
\text { equity and the environment at } \\
\text { its heart: }\end{array}$ & $\begin{array}{l}\text { ensuring that freshwater, coastal and related ecosystems are } \\
\text { protected and improved; that sustainable development and } \\
\text { political stability are promoted, that every person has access } \\
\text { to enough safe water at an affordable cost to lead a healthy } \\
\text { and productive life and that the vulnerable are protected } \\
\text { from the risks of water-related hazards }\end{array}$ & $\begin{array}{l}\text { The Hague } \\
\text { Ministerial } \\
\text { Declaration } \\
\text { (2000) }\end{array}$ \\
\hline $\begin{array}{l}\text { By far the most cited definition } \\
\text { of water security seeks to be } \\
\text { comprehensive from within an } \\
\text { otherwise reductionist } \\
\text { qualitative 'acceptable risk' } \\
\text { framing: }\end{array}$ & $\begin{array}{l}\text { the availability of an acceptable quantity and quality of water } \\
\text { for health, livelihoods, ecosystems and production, coupled } \\
\text { with an acceptable level of water-related risks to people, } \\
\text { environments and economies }\end{array}$ & $\begin{array}{l}\text { Grey and } \\
\text { Sadoff } \\
\text { (2007: 569) }\end{array}$ \\
\hline $\begin{array}{l}\text { An equally all-encompassing } \\
\text { working definition that will } \\
\text { have widespread use in global } \\
\text { institutions: }\end{array}$ & $\begin{array}{l}\text { the capacity of a population to safeguard sustainable access } \\
\text { to adequate quantities of acceptable quality water for } \\
\text { sustaining livelihoods, human well-being, and socio-economic } \\
\text { development, for ensuring protection against water-borne } \\
\text { pollution and water-related disasters, and for preserving } \\
\text { ecosystems in a climate of peace and political stability }\end{array}$ & $\begin{array}{l}\text { UN-Water } \\
\text { (2012b: vi) }\end{array}$ \\
\hline $\begin{array}{l}\text { Within a framework designed } \\
\text { to support the implementation } \\
\text { of 'pro-poor' projects, water } \\
\text { security is narrowed to: }\end{array}$ & $\begin{array}{l}\text { reliable access to water of sufficient quantity and quality for } \\
\text { basic human needs, small-scale livelihoods and local } \\
\text { ecosystem services, coupled with a well managed risk of } \\
\text { water-related disasters }\end{array}$ & $\begin{array}{l}\text { WaterAid } \\
(2012: 6)\end{array}$ \\
\hline $\begin{array}{l}\text { The working definition of water } \\
\text { security for the Department for }\end{array}$ & $\begin{array}{l}\text { sustainable and equitable access to water of appropriate } \\
\text { quantity and quality for all users (e.g. for drinking water \& }\end{array}$ & $\begin{array}{l}\text { Penrose } \\
\text { (Penrose, }\end{array}$ \\
\hline
\end{tabular}




\begin{tabular}{|l|l|l|}
\hline $\begin{array}{l}\text { International Development } \\
\text { maintains the component of } \\
\text { equity: }\end{array}$ & $\begin{array}{l}\text { sanitation, agriculture, energy, industry and ecosystems) } \\
\text { whilst reducing the impacts and costs of water shocks and } \\
\text { stresses including floods, droughts and pollution to an } \\
\text { acceptable level }\end{array}$ & 2012) \\
\hline $\begin{array}{l}\text { The most succinct definition } \\
\text { eschews comprehensiveness } \\
\text { and equity for a reductionist } \\
\text { tolerable risk' framing: }\end{array}$ & a tolerable level of water-related risk to society & $\begin{array}{l}\text { Grey et al. } \\
\text { (2013: 4). }\end{array}$ \\
\hline $\begin{array}{l}\text { Acknowledging contrasting } \\
\text { objectives of groups with } \\
\text { inequitable influence, } \\
\text { "divergent water securities" } \\
\text { has been suggested as: }\end{array}$ & $\begin{array}{l}\text { an intrinsically relational, political and multi-scale issue of } \\
\text { unequal power relations }\end{array}$ & $\begin{array}{l}\text { Boelens } \\
\text { and } \\
\text { Seemann } \\
\text { (2014: 3) }\end{array}$ \\
\hline $\begin{array}{l}\text { Directly tackling complexity } \\
\text { and uncertainty, an adaptive } \\
\text { management perspective sees } \\
\text { water security as: }\end{array}$ & $\begin{array}{l}\text { the sustainable availability of adequate quantities and } \\
\text { qualities of water for resilient societies and ecosystems in the } \\
\text { facertain global change }\end{array}$ & $\begin{array}{l}\text { Scott et al. } \\
\text { (2013). }\end{array}$ \\
\hline
\end{tabular}

The addition of the term 'security' to 'water' originally raised hopes as well as concerns amongst water research and policy communities. The hopes stemmed from the belief that the term might shake up staid thinking, which had not moved far from decades-old debates about the utility of the Dublin Principles, or the management paradigm of Integrated Water Resources Management (see e.g. Hepworth, 2009). The concerns were that the term would invite 'securitization' of water by national military-political apparatuses, which threatened to place water resource management decisions beyond the reach of normal politics (see Oswald Spring and Brauch, 2014) - though this has not developed in any meaningful way.

Even with securitization concerns allayed, however, the extent to which the term 'water security' has served to invigorate water research and policy communities is questionable. The term may still lead to broad, interdisciplinary and inclusive approaches, with security understood in the sense of reliability, adaptability, and freedom from fear. Alternatively, 'water security' could be understood in terms of predictability and control, and serve only to re-brand out-dated ideas. This article asserts that if the water security community is to take full benefit of the interest renewed by use of the term, it should debate the epistemological roots of the fault-line between the two outcomes. The fault-line is in the approach that different parts of the water security research community approach and consider the complexity of water-society challenges.

For all practical research and policy purposes, that complexity is partially composed of the nonlinear functioning and coupling of the many political, technological and biophysical processes that weave water and society together (see Grafton et al., 2013). A second source of complexity of water-society challenges comes from the uncertainty of future water availability and demand, which are themselves driven by inter-woven and constantly changing geo-political, economic, demographic, and climatic processes (see Milly et al., 2008). 
Limiting its review to literature that employs the term 'water security' with specific intent, this article categorises two major research streams on either side of the complexity faultline. It finds that the clearest research messages and policy recommendations currently on offer come from a 'security through certainty' stream that seeks to reduce the complexity through quantified risk-analysis and simplifying assumptions about national economy, hydro-climatology, and society. Policy options ensuing from an uncritical uptake of recommendations derived from this first, 'reductionist', approach may exclude a number of tested or innovative solutions, be poorly-equipped to deal with non-stationary environmental conditions, and offer little to the most vulnerable communities. Indeed, the approach risks relegating the communities to collateral-damage status or, more perniciously, accord them the blame for their own water insecurity.

A second stream of research integrates several uncoordinated tributaries that follow a general 'security through pluralism' approach, which is more comprehensive in the methods employed to understand the water-society processes, and more socially-driven and adaptive in dealing with the broadened set of uncertainties that are considered. Research carried out under this 'integrative' approach to complexity introduces novel policy options and takes advantage of the myriad context-specific techniques and solutions already in place. This latter approach currently has less reach into global water policy fora, primarily because the context-specific solutions are not readily translatable. The article concludes by defining a route towards more effective water security research and policy, which stresses the use of analysis that matches the state of knowledge possessed, an expanded research agenda, and explicit engagement with social distributional challenges.

\section{Seeking water security through certainty: the 'reductionist' approach}

The body of water security research characterised here as 'reductionist' in its approach to complexity is founded on the World Bank's Towards a Water-Secure Kenya: Water Resources Sector Memorandum (World Bank, 2004), and Sink or Swim? Water security for growth and development (Grey and Sadoff, 2007). Water security papers that build on them include Briscoe (2009); Hall and Borgomeo (2013); Grey et al (2013); Garrick and Hall (2014); and Sadoff et al (2015). Some of the original work is related to the influential World Bank Country Water Resource Strategies, notably for Ethiopia (World Bank, 2006), and many ideas generated by this research have been taken up in various policy fora, including GWP (2010), RAE (2010), OECD (2013), WWC-OECD (2015), as well as those listed in Tables 2 and 3.

The appeal of the reductionist stream of water security research comes primarily from the clarity of its messages, and from policy prescriptions that are both specific, and generalizable. Grounded primarily in engineering and economic traditions, the body of work in this stream usefully counters attempts to securitise the resource with militaristic 
strategies, and helpfully calls for the collection and more open sharing of hydrological data. As discussed following, however, its approach to complexity may lead to shortcomings when it crosses into policy-making processes, notably by a) seeking to represent uncertainty through calculable risk, b) linking national GDP tightly to hydro climatological causes, and c) overlooking diversity and politics in society.

\subsection{Reduction of uncertainty through risk framing and analysis}

Few would disagree that water security should be at least partly about analysing and reducing risk, in the colloquial sense of the term; that is, to offset "a situation involving exposure to danger or threat" (Grey et al., 2013). Using 'risk' to frame water-society challenges obliges us to think in a systematic way about uncertainty (Mason and Calow, 2012), allows easy translation across scales (Bakker, 2012), and is particularly relevant to both water-related hazards like floods (Garrick and Hall, 2014) and to the reputational concerns of business (e.g. Kelly, 2014; WEF, 2011; WRG, 2010, 2014). It also allows for recategorisation of domestic water supply challenges (e.g. Hope and Rouse, 2013; REACH, 2015), and 'speaks' to water decision-makers who must justify their budgets (Coates et al., 2012: 240). The problems arise when the logic of qualitative risk framing does not support the conclusions reached, or when the degree of certainty produced by quantitative risk analysis is undermined by its own methods and assumptions.

An example of the logic of a risk framing being pushed too far is with the assertion that the economies of countries with relatively little per capita built water storage are weak in large part because of the risk-averse behaviour their people have adopted in face of highly variable rainfall and runoff patterns - see Table 2 . The causal relationship constructed from the series of reductions reviewed there provides an unstable foundation for the policy logic that may be inferred from the message: 'deal with rainfall and runoff variability by building more storage on-farm, near cities or regionally.' The utility of such storage is limited to specific hydrological, geological and soil conditions, and so may encourage farmers in some locations (of Ethiopia, say) to take more management risks. The policy option is less practical where weather conditions are different in other parts of the country, however, and is ill-suited to confront unpredictable changes in society or climate such as rapid increases in water demand, a five-year drought, or other uncertainties that escape the risk radar. 
Table 2. Questionning complexity out of certainty 1: risk-mitigation through water storage leads to wealth.

\begin{tabular}{|c|c|c|}
\hline Introduction & Premise & Concerns \\
\hline $\begin{array}{l}\text { When scientists } \\
\text { actively seek to inform } \\
\text { policy, they attempt to } \\
\text { distil down ideas and } \\
\text { simplify intricacies - at } \\
\text { the danger of boiling } \\
\text { away the substance or } \\
\text { becoming overly } \\
\text { deterministic, as in the } \\
\text { following figures. A } \\
\text { variation of World } \\
\text { Bank (2004: Fig 4.2), } \\
\text { the first figure is } \\
\text { reproduced or } \\
\text { adapted in a number } \\
\text { of articles, } \\
\text { presentations and } \\
\text { reports (e.g. Briscoe, } \\
2009 \text {; Grey, 2012; } \\
\text { Salzberg, 2009; UNEP, } \\
2008 \text {; Whittington et } \\
\text { al., 2009), while the } \\
\text { second has been taken } \\
\text { up in Sadoff et al } \\
\text { (2015: Box 1). }\end{array}$ & $\begin{array}{l}\text { The first figure compares the 'built } \\
\text { reservoir capacity per capita' of } \\
\text { Ethiopia ( } 38 \mathrm{~m}^{3} / \text { person) with other } \\
\text { countries, and North America } \\
\text { (5,961 } \mathrm{m}^{3} / \text { person). While the paper } \\
\text { acknowledges the substantial social } \\
\text { and environmental costs of the } \\
\text { hydraulic infrastructure required to } \\
\text { provide water storage, the } \\
\text { suggestion is that the predictability } \\
\text { provided by the protection against } \\
\text { flood and drought enables } \\
\text { economies to flourish. The second } \\
\text { figure tests the idea on large river } \\
\text { basins, tying built storage with } \\
\text { institutional capacity, and using } \\
\text { variation in runoff as an indicator } \\
\text { of 'hydrologic variability'. Countries } \\
\text { that form part of basins benefitting } \\
\text { from high investment to reduce or } \\
\text { manage water-related risk have a } \\
\text { greater GDP, it is suggested, even if } \\
\text { they have more hydrological } \\
\text { variability. Risk framing steers the } \\
\text { reasoning behind both figures: } \\
\text { unpredictable variability in rainfall } \\
\text { and runoff leads to "risk-averse } \\
\text { behaviour" (Grey and Sadoff, } 2007: \\
551 \text { ), which constrains national } \\
\text { economic growth. }\end{array}$ & $\begin{array}{l}\text { Farmers benefit from more reliable and } \\
\text { predictable supplies of water, of course, and if } \\
\text { an entire economy can be 'climate-proofed' } \\
\text { against variability, it certainly has an } \\
\text { opportunity to thrive. However, a number of } \\
\text { issues with the figures call the reasoning } \\
\text { provided into question: The omission of } \\
\text { countries that would belie the trend suggested } \\
\text { (where would low per capita Singapore be } \\
\text { placed? high per capita Ghana?); the lack of } \\
\text { consideration of in-country rainfall and flooding } \\
\text { patterns, and natural flood defences or } \\
\text { adaptation; the neglect of the multiple non- } \\
\text { water ecosystem functions provided by healthy } \\
\text { freshwater systems, including fish protein, } \\
\text { floodplain sediment replenishment or carbon } \\
\text { sequestration; the inclusion of large amounts of } \\
\text { 'dead' storage from extremely large } \\
\text { hydropower dams that serve no flood 'buffer' } \\
\text { or drought prevention purpose; and the } \\
\text { apparent reconciliation of irreconcilable } \\
\text { national political borders and river basin } \\
\text { boundaries. Even the data themselves are } \\
\text { belied by different analyses (see McCartney } \\
\text { and Smakhtin, } 2010 \text { : Box } 1 \text { ). The message that } \\
\text { economic wealth is derived from increased } \\
\text { water storage or low run off because these } \\
\text { mitigate individual risk leads to firm } \\
\text { recommendations (i.e. build more storage, } \\
\text { improve institutions), but the foundation upon } \\
\text { which it rests is not secure. }\end{array}$ \\
\hline
\end{tabular}

Built reservoir capacity in 2003 ( $y$ axis, $\mathrm{m}^{3}$ per capita) in select countries (and one continent) (Grey and Sadoff, 2007: Fig 3). Permission to reproduce to be sought.

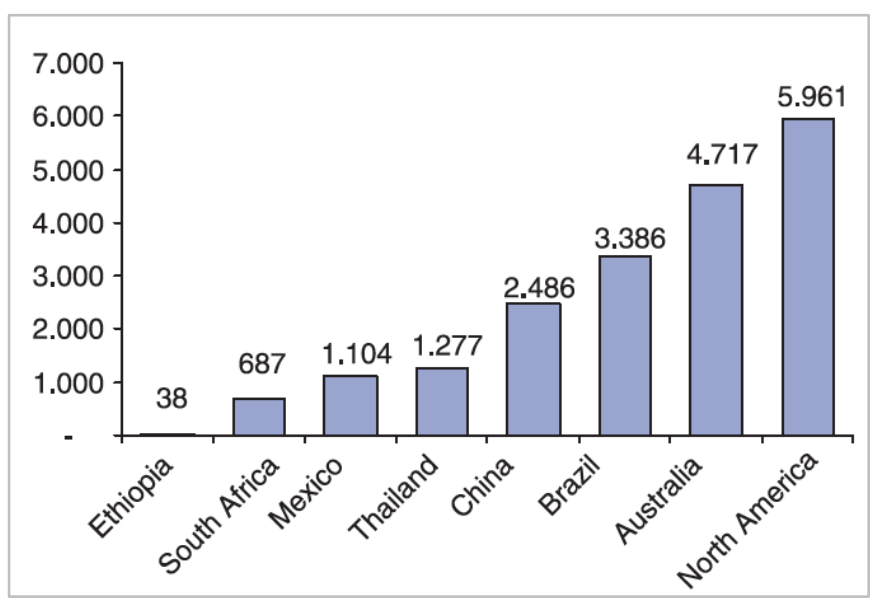

Built reservoir capacity and institutional capacity vs. variation in monthly runoff, for populous river basins (Hall et al., 2014: Fig 2). Permission to reproduce to be sought. 


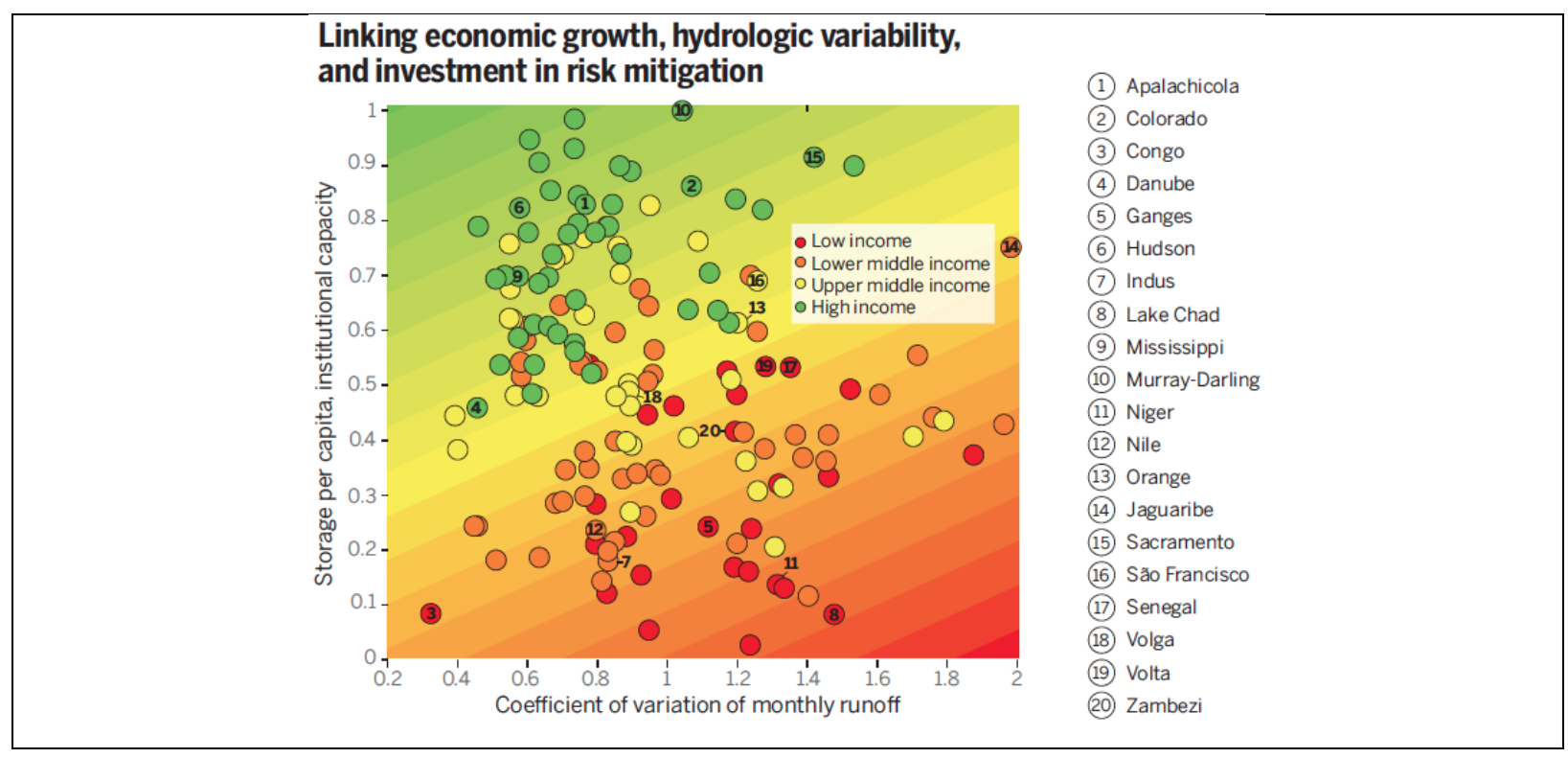

Policy deriving from quantitative risk analysis may be even more likely to suffer from overreach. Over-simplification of complex challenges through an inappropriately narrow focus on probability as part of the formal risk framing is an inadequate response to incomplete knowledge, yet, as Stirling (2010: 1029) notes, encourages "policy-makers to pursue (and claim) 'science-based' decisions" (see also Beven, 2008; New et al., 2007). As Hall and Borgomeo (2013: 18) warn, "[a]dopting a probabilistic representation of uncertainty when it is not warranted by the available evidence can lead to assessments of risk that underestimate the total uncertainty and adoption of management responses that are vulnerable to those uncertainties" (see also Pahl-Wostl, 2016: Box 6.2) Risk cannot be managed if it cannot be adequately understood and measured, in other words.

Claims that the formal risk appoach can incorporate highly uncertain non-stationary climatic conditions adequately for water security analysis (as in Hall and Borgomeo, 2013: 17) therefore call for investigation of the uncertainties that might be passed over. Here, a modelled assessment of water security in England is "idealized" for being limited to model uncertainties of the chosen climate scenarios (see AGWA, 2013); water use in the south of the country; and only a small number of the many relevant actors. As the ongoing waterrelated conflict generated by the introduction of hydraulic fracturing in the UK reveals, water governance in England is afflicted with uncertainties driven not just by new technologies and the way people may support or oppose environmental policy, but by future energy demands that are driven by global biophysical and economic processes, as well as the regional politics of the European Union - factors which are beyond the grasp of probability and functionality. If, as in this example, the role of people and climate is overlooked or over-simplified in contexts where climate and social data are relatively readily available, management responses are likely to be yet more vulnerable to simplifying assumptions where there are even less data available. The very concern raised by the authors about conclusions drawn from unwarranted evidence is proven unable to counter the allure of the application of the method. 
The range of applicability of quantitative risk analysis for water security research is thus restricted to contexts that are very well studied, with well-bounded (and thus 'known') conditions. It can thus take its place as one option within the plurality of approaches required to address water security, in particular with land-use planning decisions in the face of droughts (Brown et al., 2013) and floods (Sayers et al., 2014). Critical eyes must remain open, meanwhile, for the potential misinterpretation of quantified risk as 'real', or 'fixed' in any way, particularly in situations of great complexity and uncertainty. It is not surprising to witness cases where policy-makers jettison the notes of caution raised by researchers, and take action without due consideration of the unknowns - as a separate study on UK floods has shown (Kuklicke and Demeritt, 2016). The same study draws attention to a less foreseeable appeal of simplified messages: uncertainty may be deliberately ignored by policy institutions that are concerned about their own reputational risk (Kuklicke and Demeritt, 2016: 65), who thus legitimise rather than question the validity of the approach.

\subsection{Reduction of swings in GDP to hydro-climatological causes}

Another possible knock-on effect of the adoption of clear and simple (if unfounded) policy recommendations is the reinforcement of interests already invested in the water and development sectors, because different groups have very different influence over the science-policy process. There is thus reason to reflect upon the extent to which the status quo is likely to be challenged, when the role that water resources play in societies is reduced to a simple deterministic relationship between rainfall or runoff, and national GDP.

To return to the case of Ethiopia (Table 3), the idea that national GDP is closely linked to rainfall does not stand up to statistical scrutiny, even though certain ways of presenting relationships visually may appear to tell a different story. The incorporation of other hydroclimatic variables and basin-specific and annual global effects into the analysis (such as modelled evapotranspiration (Sadoff et al., 2015))) refines the message, to a degree. The second-generation analysis still fails, however, to explicitly take into account the many complex reasons beyond hydrological variability that influence a country's GDP. These include political stability, international trade, level of industrialisation, and education levels, to name just a few (see Merrey (2009), Hatfield-Dodds (2006). A policy correlation between reservoir storage and GDP also incorrectly assumes a linear and equitable share of GDP for marginalised and poor people (see Calow and Mason, 2014; Dercon, 2012). 
Table 3. Questionning complexity out of certainty 2: GDP links with rainfall.

\begin{tabular}{|c|c|c|}
\hline Introduction & Premise & Concerns \\
\hline $\begin{array}{l}\text { The rainfall vs. GDP } \\
\text { growth graph } \\
\text { shown in the first } \\
\text { figure below is } \\
\text { seen frequently at } \\
\text { global water fora, } \\
\text { and reproduced or } \\
\text { taken further in } \\
\text { journal articles and } \\
\text { policy reports } \\
\text { (Delli-Priscoli, } \\
\text { 2012; DFID, 2009; } \\
\text { Muller et al., 2009; } \\
\text { Petherick, 2012; } \\
\text { see also REACH, } \\
\text { 2015; Sadoff and } \\
\text { Grey, 2008; Sadoff } \\
\text { and Muller, 2009; } \\
\text { The Economist, } \\
\text { 2009; van Aalst et } \\
\text { al., 2007; e.g. } \\
\text { World Bank, 2006; } \\
\text { WWDR, 2009: 82). }\end{array}$ & $\begin{array}{l}\text { The figure tracks the } \\
\text { national and agricultural } \\
\text { GDP growth of Ethiopia } \\
\text { against rainfall variability, } \\
\text { from } 1982 \text { to 2000. A very } \\
\text { "sensitive" relation is } \\
\text { suggested for most years } \\
\text { (Grey and Sadoff, 2007: } \\
\text { 557); that is, strong } \\
\text { economic growth seems to } \\
\text { follow years of heavy rain, } \\
\text { and droughts appear to } \\
\text { precede economic declines. } \\
\text { The paper asserts that } \\
\text { poverty is associated with } \\
\text { the "hydrologic variability" } \\
\text { of a country, whereas water } \\
\text { infrastructure and } \\
\text { institutions that might } \\
\text { mitigate the variability, } \\
\text { along with "market } \\
\text { infrastructure", are coupled } \\
\text { to national economic } \\
\text { wealth. "The overall impact } \\
\text { is that Ethiopia's economic } \\
\text { growth is tied tightly to the } \\
\text { rains" (Grey and Sadoff, } \\
\text { 2007: 557). Caveats } \\
\text { provided point out that the } \\
\text { association between } \\
\text { hydrological complexity and } \\
\text { GDP growth does not mean } \\
\text { causality, though the } \\
\text { association is upgraded (in } \\
\text { Grey, et al. 2013) to a } \\
\text { "relationship". Thus are } \\
\text { linear cause and effect } \\
\text { dynamics andently } \\
\text { distilled from the otherwise } \\
\text { multi-faceted interaction } \\
\text { between water and society. }\end{array}$ & 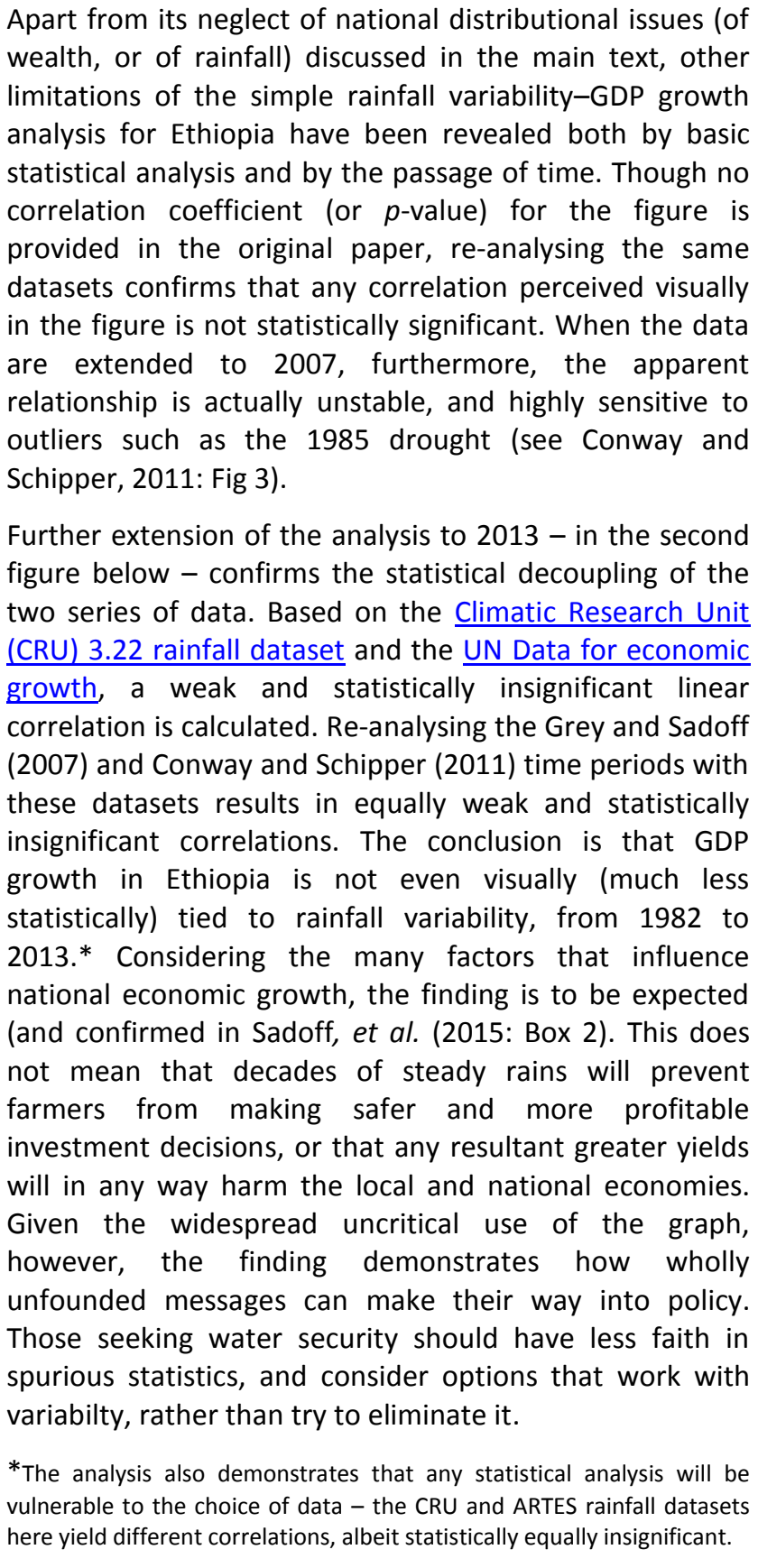 \\
\hline
\end{tabular}




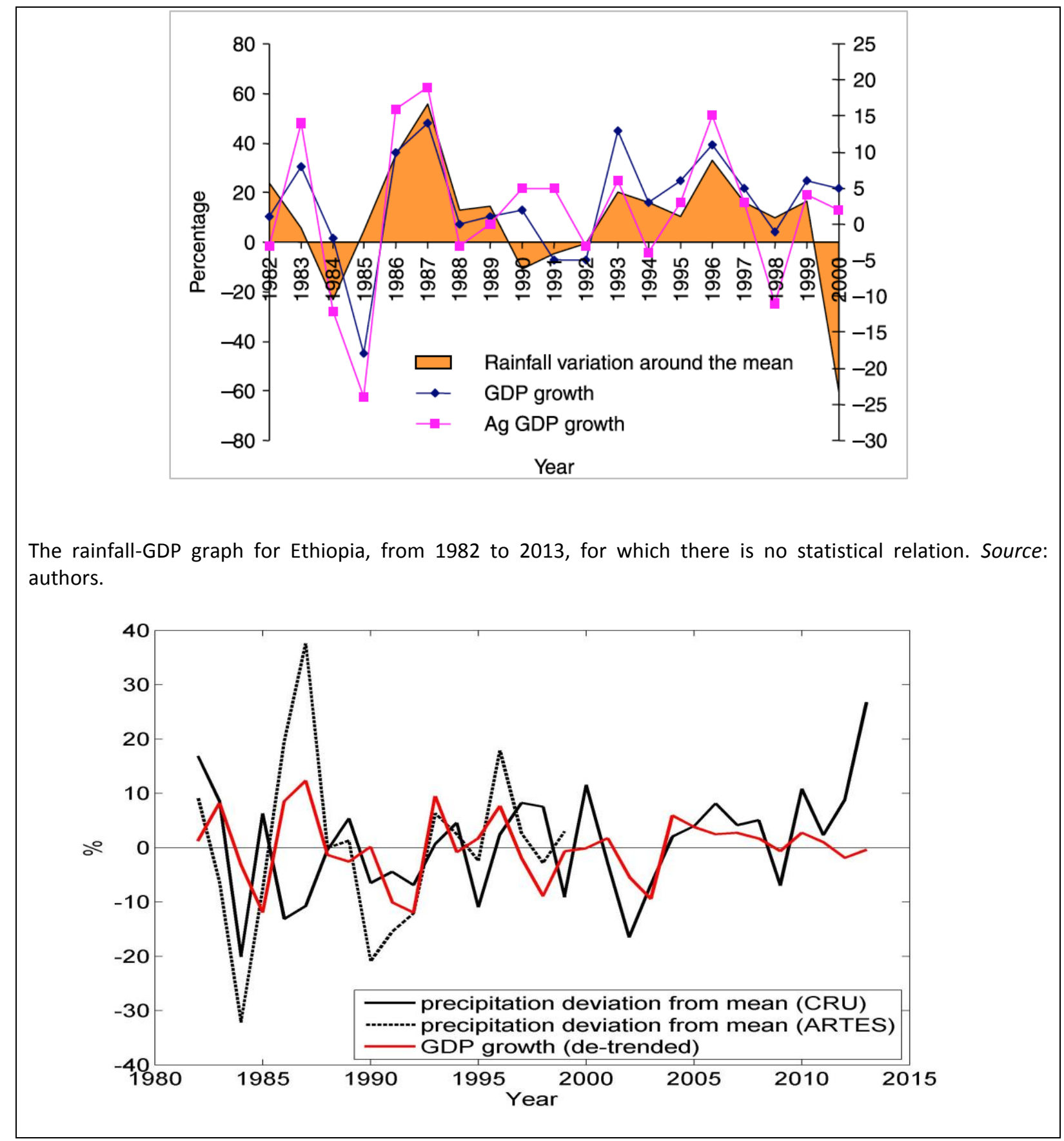

As before, the concern is less with the hydro-economic modelling method chosen than with its use in situations where it is not warranted, and so with how the results may shape policy. If policy-makers and influencers see national economic growth as inversely related to rainfall or runoff variability, they are likely to support the clear and simple policy recommendations derived from these causal links, regardless of the caveats provided. Harking back to classic water resources management, the policy recommendations backed by the researchers in this stream are arranged to facilitate increasing water supply and narrow conceptions of water use efficiency, and are posed as investments in hydraulic infrastructure and institutions (Garrick and Hall, 2014; Grey and Sadoff, 2007), and hydrological information (Grey et al., 2013; Hall et al., 2014; Sadoff et al., 2015). 
Lending banks and financial institutions have been immediately drawn to the much higherexpenditure recommendation to invest in infrastructure, possibly to the exclusion of investment in institutions and information (see WWC-OECD, 2015). The way is thus paved for the benefits of dams, canals and storage schemes, but quietly and very effectively blocked for consideration of some of their downsides: an inability to adapt to future hydrosocial-climatic conditions ('lock-in'); a lack of fit to existing and especially micro-scale/local infrastructure that distributes water (Lankford, 2013); the "false sense of security" engendered, for instance, by levees (Palmer et al., 2015: 585) and considerable but concealable social, ecological and economic costs (Flyvbjerg, 2014; Matthews and Geheb, 2015; World Bank, 2015). Who pays for the removal or replacement of the infrastructure once it is obsolete is one of the more pressing questions raised (Doyle and Havlick, 2009). The concern remains even if the accompanying regulatory and enforcement frameworks are strong and purposively flexible to meet ever-changing conditions, which is often not the case. This supply-side logic has mis-served governments in Australia (Pegram et al., 2013), Central Asia (Varis, 2014), Spain (Rovira and Polo, 2015), or along the Orange-Senqu, Yellow, and Colorado Rivers (Grafton et al., 2013), who must now deal with simultaneous overcapacity of hydraulic infrastructure designed for specific conditions, and the over-reliance of their constituents upon it for water, whenever the rains 'fail'.

The inflexibility of the approach is further compounded by being restricted to water resources that are easily measured, or 'engineered', like surface water. Left out of the equations is water in the aquifers, or soil. No matter how robust the statistical analysis is, research undertaken in the name of water security that does not consider groundwater (e.g. Brown et al., 2013; Vörösmarty et al., 2010) bypasses the millions of farming livelihoods and all of the food provided through groundwater-irrigated agriculture, not to mention the millions who rely on it for drinking. Similarly, basin-level analyses that neglect the role of soil-water in achieving water security (e.g. Sadoff et al., 2015: Fig 1), obscure the communities dependent upon rainfed agriculture, and so shuts out policy that may be derived from the adaptable livelihood strategies they have developed, as well as green/blue water management and other innovations discussed later.

\subsection{Reduction of diversity and politics in society}

An even greater number of policy options are excluded through attempts to reduce the complexity in society. The 'tolerable risk' definitions of water security at first appear inclusive and considerate of the most vulnerable: e.g. "water security is a tolerable level of water-related risk to society" (Grey et al., 2013: 4) (see also Grey and Sadoff (2007: 569) and Table 1). The definitions imply, however, that 'all' in society have relatively equal influence over their situation, when in reality some people bear the 'risky' consequences of other people's choices.

If you are prevented by your income, gender, religion or nationality from accessing water that is available to others, it is of little use that (the rest of) 'society' can tolerate the risk you 
face. It is in this sense that citizens of inner-city Detroit (Blue Planet, 2014), street kids in Mumbai (Hanchett et al., 2003), women in rural Ghana (Venot and Clement, 2013), and Palestinians throughout the West Bank and Gaza (Selby, 2013) are water insecure. Though these and many other marginalised communities have been the targets of locallyimplemented and internationally-funded water security-type projects and programmes, they are likely to remain water insecure so long as the cultural biases and political exclusions that in large part prevent them from accessing water on equal terms with others continue to be downplayed.

For clarity and effectiveness, then, water security policy and projects aimed at the most vulnerable should ask the question, who benefits? An appreciation of power asymmetries suggests that the group that benefits the most might often be the very group that defines what level of risk is tolerable for other groups, through the trade-offs that must be made when everyone cannot benefit equally. It is the landowners in Pakistan who define the tolerable level of water-related risk when they choose to protect their fields rather than their neighbours from floods, for example (BBC, 2010). The wealthy and powerful can also use insurance or influence over reconstruction permits to externalise threats in ways that are not typically available to the marginalised in society (Collins, 2009; Mustafa, 2012).

In this sense, the advice that "tolerability of risk will depend on the size of the population, with societies tending to be averse to very large-scale losses to people" (Hall and Borgomeo, 2013: 8) is a cynical turn against both vulnerable communities and individuals. As the 'security through certainty' stream of water security research evolves, then, it discards the elements of fairness that were implicit in its foundational work. Yet, the greatest problem with avoiding the politics so integral to allocation of and access to water is that it can lead to a view of poverty and water insecurity seemingly being "the fault of one's birthplace rather than the outcome of a set of social relations that can be transformed" (Loftus, 2014: 3).

\section{Seeking water security via complexity - the integrative approach}

The term 'water security' has also animated a great body of research that is tailored to particular challenges or communities, and does not necessarily seek to generalize. The diverse tributaries to this stream develop independently throughout the world, and across a very wide range of disciplines. They generally tend to approach the complexity of the watersociety challenges either by invoking more comprehensive analysis of the underlying processes, or by being socially driven and adaptive in the face of a broadened set of uncertainties that are considered.

The inclusive spirit of this stream of water security research may evoke comparisons with the paradigm of Integrated Water Resources Management, or IWRM (e.g. Cook and Bakker, 2012; Savenije and van der Zaag, 2008). IWRM served to steer thinking away from 'classic' water resources management that was based on notions of environmental equilibrium 
conditions, was isolated from forestry and agriculture, and employed a top-down view of scientists and decision-makers in society. However, these very roots in classic water resources management also limit the utility of IWRM: it problematically employs the river basin as a unit of analysis, and avoids the politics that can serve to manage trade-offs (amongst many other critiques, see e.g. Allan, 2003; Pegram et al., 2013; Warner et al., 2008). By contrast, the integrative body of water security research extends to industrial and domestic water challenges, can accommodate many different forms of analysis, and - by virtue of the 'freedom from fear' element included in the term 'security' - cannot (and does not) invite claims of being apolitical. By the definition provided here, furthermore, integrative water security research is obliged to confront complexity in a way that IWRM will never be.

Analysis and policy framed in an 'integrative' manner may share the understanding that it is better to be imprecise and correct, than precise but wrong (see Gunderson, 1999; LWEC, 2014; UN-Water, 2012a). This is a precautionary philosophy, consistent with the international water-law community's approach to uncertainty with respect to the nature and extent of poorly explored aquifers (Hawkins, 2015; UN ILC, 2008: Art 12), in keeping with the environmental philosophy critique of humankind seeking control over nature (Read, 2015), and compatible with the response to dynamism created by non-equilibrium hydroclimatic and rapidly changing social conditions (see e.g. Lankford and Beale, 2007; Leach et al., 2010; Scott et al., 2012).

Very generally, the uncertainties of any particular complex challenge may be approached through planned redundancies in systems, reversible infrastructure, an 'architectural systems' approach to infrastructure types (Lankford, 2013), or decision frames that are robust in the sense that they expliciltly seek to incorporate many perspectives. Much of this water security research aligns with the reductionist approach in so far as it sees increased reliability of supply as a key component to water security in many contexts. But only so long as reliable supply is not separated from equitable distribution of and access to water, or from environmental sustainability throughout the hydrological wet-dry regime (see e.g. van der Zaag and Gupta, 2008). The resultant policy recommendations are more context-specific, and may respond better to dynamic hydro-climatological and social conditions.

Recommendations to sequence investments in infrastructure, institutions, and information are thus supplemented by calls for support to soil-water management programmes, food trade opportunities, more equitable governance arrangements, and many others. Policy that may have been influenced by this stream includes WaterAid (2012), ADB (2013), and Calow, et al. (2013), though it cannot be said to have the same policy influence as the work of the reductionist approach.

More specifically, the 'integrative' body of water security research grapples with the complexity of water-society challenges by: a) explicitly recognising diversity in society and the environment, while maintaining focus on the most marginalised; b) incorporating water 
resources that are less-easily controlled into the analysis; and c) welcoming innovative and adaptive approaches to move beyond supply-side prescriptions.

\subsection{Working with diversity and inustice in society and the environment}

Many of the integrative water security research tributaries see water as an intrinsically relational, political and multiple-scale issue of both water access and control (from Boelens and Seemann, 2014, and see Table 1). This is a recognition of the paradox of any water security measure; that is, that water security for some communities can come at the cost of water (or food, energy, or climate) insecurity of others, as for instance in the case of UK consumption of asparagus grown through over-pumping the aquifers of the IcaHuancavelica valley in Peru (Hepworth et al., 2010; Zeitoun, 2011).

This stream of water security research seeks to reduce the complexity of social diversity without over-simplifying it, which is no easy task (see Schmidt, 2012). While it is clear in some situations who the winners and losers of any policy may be, other situations would likely require the context-specific understandings of exclusion that can be provided, for instance, by the heavy weight of evidence collected through ethnographic water security studies (e.g. Vera Delgado, 2011), or by working explicitly with those people most intensely affected through trans disciplinary research approaches (Krueger et al., 2016). Research targeted at the individual or community by linking water security with human security (e.g. Allouche et al., 2014b; Gerlak and Wilder, 2012; Jepson, 2014; Leb and Wouters, 2013), or that specifies water security for whom? (e.g. Warner and Johnson, 2007) is equally vital for policy effectiveness.

The research finds that the causes of inequitable distributions of benefits and risks are often best attributed to a political economy that disadvantages those who are already vulnerable or marginalised (see Mason and Calow, 2012). Effective water security policy might therefore oblige confrontation of the political, economic and technological arrangements that some may judge as unfair or unsustainable, even where more powerful actors might argue these are reasonable. Such interventions are, in fact, attempts to steer the inevitable trade-offs towards more vulnerable communities, in the true sense of a subjective 'pro-poor' policy.

Water policy research employing a 'justice' lens to expose the institutional and cultural barriers to adequate drinking water services in Africa, Asia and Latin America (e.g. Budds and McGranahan, 2003; Zeitoun and McLaughlin, 2013; Zwarteveen and Boelens, 2014) may shed light that can serve to reform these structures. Other examples include the investigations that have served to shake the complacency of ministries and donor-created Water User Associations in South Africa (Kemerink et al., 2013), as well as those that have compelled the re-allocation of water to indigenous groups in Australia (e.g. Nikolakis and Grafton, 2014). Apart from the blending of social attributes with physical attributes to improve water security indicators (e.g. Lautze and Manthrithilake, 2012; Mason, 2013; 
Norman et al., 2013), however, the water security research community on the whole has hesitated to move in this direction.

The inescapable trade-offs that accompany any new project or policy may go against the environment as well, with the continued elimination of species predictable under a global political economy that encourages non-industrialised countries to follow the same trajectories as industrialised ones (see Sachs et al., 2009). As Palmer (2010: 534) puts it, "water security increases with affluence (higher gross domestic product) - but so do threats to biodiversity. In fact, the very actions taken to increase water security, such as the building of dams and flow diversions, typically result in habitat loss and changes to river flow that act to reduce both fish diversity and water quality" (see also Steward-Koster and Bunn, 2016; Tickner and Acreman, 2013). Europe's decimation of its freshwater ecosystems prior to the recent trend of river restoration is a case in point (WWF, 2014).

Efforts to grapple with the inequitable aspects of social diversity are vulnerable to the same drawbacks as all policy-oriented research, notably a bias towards more influential communities (Cooke and Kothari, 2001), elite capture (Krishnan and George, 2009), or misinterpretation by policymakers (Patrick et al., 2014). The context-specific focus of much of the research under this stream furthermore limits its easy generalizability, and so the support also of donors seeking large-scale development to guarantee returns on investment. By challenging the simple messages of the reductionist approach to water security, furthermore, the integrative stream simultaneously runs the risk of backgrounding useful conventional interventions (about e.g. reservoir storage), while producing findings that are not always politically expedient.

\subsection{Beyond the river: incorporating water that is less-readily controlled}

Properly integrated water security research must deal with the manner in which the very many interdependent social and biophysical processes combine, and the multiple scales at which they do so. Water security analysis must therefore go well 'beyond the river' (Sadoff and Grey, 2002), and water flows that are readily measured and controlled.

The established body of groundwater-related water security research (Famiglietti, 2014; Foster and MacDonald, 2014; see e.g. Taylor et al., 2013) joins the growing body of work on 'green' (soil) water to contribute to the development of analytical methods for global water accounting (Karimi et al., 2013; Lawford et al., 2013) and global food security (Allan, 2013; Falkenmark, 2013; Lundqvist, 2000; Warner and Johnson, 2007), as well as policy based on green-blue water management (Dent and Dalal-Clayton, 2014), and adaptation to climate change (Conway, 2013; Osborn et al., 2015). Considering further that most soil-water used by humans is managed by farmers (and so out of the direct reach of governments and large corporations (Allan, 2011)), inclusive governance arrangements that make the most of different aspects of society, for example, may be more comprehensive than classical formal institutions, now and in the future (see Norton, 2014). 
The interwoven social and biophysical processes, connected in the hydro-social system (Linton, 2014), lead to interdependencies with other resources, and so to climate, food, and energy security. Any form of sustainable water security policy must therefore consider these wider 'nexus' issues (see Allouche et al., 2014a: 6), and debate, for instance, whether water in agriculture is to be used to produce food or biofuel, or whether at the basin level water is to be allocated for agriculture, ecosystems, public drinking water supply, or energy generation (Scott et al., 2011). There is certainly a lack of water security research relating local water dead-ends and cycles with larger hydro-cycles, however, just as there is a great need for even further integration with earth observation and climate research (e.g. Vörösmarty et al., 2013). Further efforts must equally go beyond the 'water box' entirely, to incorporate the influence of ministries of finance, trade boards, multi-national corporations and local private-sector actors (not only farmers), all of whom are involved in global food / virtual water trade and global sustainability challenges (e.g. Seekell et al., 2011).

As with water security research that challenges established patterns of social distribution, policy options derived from this body of work are engaged in an uphill trek. The institutions required to run them will have to span departments of government and administrative jurisdictions that have been entrenched for decades. The infrastructure required is typically less grand and more dispersed, so that even if better 'matched', is less attractive to invest in.

\subsection{Beyond supply-side prescriptions: welcoming adaptive approaches}

Adaptation and flexibility are tenets central to uncertain futures (see e.g. Hall et al., 2014: 430), particularly given the problems with infrastructure 'lock-in'. Adaptive approaches also serve to integrate people's ingenuity, and have been shown to be the most effective when potential pitfalls cannot be adequately characterised (see Stirling et al., 2007: Fig 5).

Analytical approaches to complexity that appreciate social diversity can thus supplement locally relevant blends of adaptation as well as appropriate (if "clumsy") infrastructure and technology (see e.g. García et al., 2014: Ch 4; Matthews et al., 2011; Palmer, 2010; Verweij and Thompson, 2006). For example, combined storage options are more adaptable than single storage systems, and hence provide better 'security' against the vagaries of rainfall (McCartney and Smakhtin, 2010). Integration of the lessons of adaptive water management into water security (see Pahl-Wostl et al., 2013a; Scott et al., 2013) move beyond measures to increase 'water use efficiency' in production, to focus instead on learning, adapting, and consumption patterns (see also Clement, 2013), very much like the adaptive stream of 'climate-smart' agriculture. Allan et al. (2013) for instance, make a convincing case for the utility of adaptive water management for dealing with the social-ecological complexity of water security in China's National Water Policy, the European Floods Directive and Australia's Murray-Darling Basin Plan (see also Raadgever et al., 2011; Sigel et al., 2010). The more that research and policy develops along these adaptive and flexible lines, the more creative and responsive conceptualisations of water security can be. The integrative water security research community appears to be gradually leaning away from viewing security simply in terms of sufficiency, or in terms of eliminating variability, and towards the 
type of water security that comes through recognition of shared responsibilities, just as thinking about the global commons must and does challenge dated notions of absolute territorial sovereignty.

\section{The route to effective water security}

This article has asserted that realising the full conceptual, analytical, and policy benefits of 'water security' depends largely on how the complexity of water-society challenges is considered and approached. This complexity is shaped by nonlinear and interwoven political, biophysical and technical processes, as well as by the severe uncertainty of future water availability and demand.

Two approaches have been discussed: a policy-friendly approach that seeks to reduce complexity through risk analysis and simplifying assumptions about national economies, hydro-climatology, and society; and a more pluralistic approach that broadens both the range of uncertainties considered and the analytical methods by which to integrate them. Laid-out in this way, the 'complexity fault-line' between the two approaches is certainly often blurred (some nexus work that might otherwise be labelled integrative here, for example, tends to underemphasise distributional issues (see Allouche et al., 2015)), but the distinction does serve to highlight key concerns, and how they may be addressed.

The main concern is that the allure of the 'reductionist' approach in policy-circles can lead to the premature closure of useful options that might otherwise be opened by the 'integrative' approach, in much the same way that some physical climate science circles ignore the contributions of social climate science (see Castree et al., 2014). This analysis has shown that the reductionist approach is problematic because a) at least some of it is insufficiently grounded to justify the support it provides to large investment plans, b) the uncertainties that are veiled by some of these approaches are the very ones that can render resultant policy recommendations ineffective, and c) downplaying of social distributional issues and power asymmetries will tend to favour the wealthy and powerful over the marginalised. If it is to prove of use, the term 'water security' needs to be rooted, expanded, and attuned to social justice.

The analysis thus not only justifies more space for an 'integrative' approach to water security in policy circles, but it also sketches three landmarks on the route to more effective water security. First, the form of water security analysis must match the level or state of knowledge possessed. Formal quantitative risk analysis works best when the incomplete knowledge possessed is related to familiar systems under controlled conditions with sufficient and reliable data. It might prove suitable for predicting and protecting against floods in well-studied areas (Stirling et al., 2007: Fig 1), for example, but is not to be trusted where data is poor or where the reputational risk of policy institutions may distort. Qualitative and quantitative risk framing also falls down when stretched too far, as in linking 
national economic growth with hydrologic variability, or built reservoir capacity with poverty. It is in this sense that the presentation of the graphs of Tables 2 and 3 to policymakers is as misleading as it is narrowing.

When our collective level of knowledge is characterised by ignorance, ambiguity or uncertainty, a systematic analysis that explores the real limits of our understanding is more effective. This holds for social appraisals of sustainability (e.g. Stirling et al., 2007: Ch 3), to define 'critical' hydrologic indicator thresholds (Singh et al., 2014), or for the design of water resource infrastructure systems (Brown, 2010), for example. Lessons that this body of work hold for water security research and policy include the rationale for broadened, precautionary, and more humble approaches and perspectives in the face of unknown unknowns. Along with the many types of analysis noted here, qualitative risk framing that draws attention to hydro-climatic hazards and social vulnerabilities can be a useful complement to such efforts, when it is properly founded.

The second landmark on the route to more effective water security is an expanded research agenda. This is a collective task to more accurately stake-out the useful range of the reductionist approach, as well as to begin to address the very many gaps that exist (as PahlWostl et al (2013b) have done at the global level). Gaps identified here include more coherent accounting of water movements within a system (to include soil-water and groundwater, at the very least) (see e.g. Simons et al., 2015); a better understanding of the interaction of global and local weather and climate processes, through integration of hydrology, hydrogeology and agronomy with climate and social science; systematic consideration of the influence of processes beyond the water box (e.g. food trade, international agreements); improved integration of the findings with established thinking on appropriate infrastructure and technology; improved documentation of experience with adaptation management techniques (DFID, 2015; see Hallegatte, 2009); integration of the thoughts on 'water tenure security' (Hodgson, 2016); and a better understanding of the way that political and economic systems, corruption, and transparency influence all of the above (Matthews and Schmidt, 2014). There is also considerable gain to be had by combining extensive comparative research into water security processes and outcomes with deeper contextualised work on how local variations in water security occur. Local understandings of water security may provide the best entry point to move beyond the institutional barriers that maintain inequity.

Finally, if water security research is to serve policy that will reach those most negatively impacted by resource allocation, both today and in the uncertain future, it must explicitly address inequity in outcomes. If anything related to water security is to be reduced, let it be ambiguity about objectives. Water security research and policy will be more effective if the meaning and intended target of the 'security' is declared, whether it means the elimination of variability in the (impossible) pursuit of water security 'for all', market-driven reliability for the most efficient use or user, or social justice for the marginalised. Constant integration of power asymmetries into the analysis is helpful here, as argued in Bakker and Morinville 
(2013) (with more specific discussion of the dynamics and decision frameworks provided in Geels (2014) Zeitoun, et al., (in press); Poff, et al. (2015)). Though no single water security definition is ever likely to serve all purposes, an indicator of too much drift back towards classic water resources management and IWRM is that social aspects are downplayed, and politics ignored.

This last point raises ethical questions that should be discussed. If for example some of the causes of water insecurity are accepted as structural, is positive discrimination against those already benefitting from the arrangement (the way carbon-intensive lifestyles of the wealthy might be taxed to facilitate climate change adaptation) morally grounded? Is it legitimate for those of us who are so far removed from the consequences of our research and policy to exclude those who are most directly affected?

Engaging in these debates will help ensure that 'water security' becomes a paradigm that recognizes and grapples with the complexity of water across social, political, economic, and climatic dimensions. 'Water security' must remain a term that constantly reminds us that in tackling complex challenges at the interface of water, society and climate there is no single response, no irrevocable scientific 'truth', no easy unifying narrative. Instead, there is a critical need to be flexible, to ensure adaptability, and most of all to ensure that watersociety-climate research and policy always keep in sharp focus those for whom water insecurity is an everyday struggle. 


\section{References}

ADB, (2013) Asian Water Development Outlook 2013: Measuring Water Security in Asia and the Pacific. Asia Development Bank and Asia-Pacific Water Forum, Mandaluyong City.

AGWA, (2013) Caveat Adaptor: The Best Use of Climate Model Simulations for Climate Adaptation \& Freshwater Management, White Paper 1. Alliance for Global Water Adaptation (World Bank and Stockholm International Water Institute).

Allan, C., Xia, J., Pahl-Wostl, C. (2013) Climate change and water security: challenges for adaptive water management. Current Opinion in Environmental Sustainability 5, 625-632.

Allan, J.A., (2003) IWRM/IWRAM: Integrated water resources allocation and management: a new sanctioned discourse?, in: Mollinga, P.P., Dixit, A., Sthukorala, K. (Eds.), Integrated water resource management in South Asia: global theory, emerging practice and local needs. SaciWATERs, Hyderabad.

Allan, T. (2011) Virtual water: tackling the threat to our planet's most precisou resource. I.B. Tauris, London.

Allan, T., (2013) Food-water security: beyond hydrology and the water sector, in: Lankford, B., Bakker, K., Zeitoun, M., Conway, D. (Eds.), Water Security: Principles, perspectives, practice. Earthscan, London.

Allouche, J., Middleton, C., Gyawali, D., (2014a) Nexus Nirvana or Nexus Nullity? A dynamic approach to security and sustainability in the water-energy-food nexus, STEPS Working Paper 63. Institute of Development Studies, University of Sussex, Sussex.

Allouche, J., Middleton, C., Gyawali, D. (2015) Technical Veil, Hidden Politics: Interrogating the Power Linkages behind the Nexus. Water Alternatives 8, 610 - 626.

Allouche, J., Nicol, A., Mehta, L. (2014b) Water Security: Towards the Human Securitization of Water? The Whitehead Journal of Diplomacy and International Relations XII, 153 - 172.

Bakker, K. (2012) Water Security: Research Challenges and Opportunities. Science 337, 914 915.

Bakker, K., Morinville, C. (2013) The governance dimensions of water security: a review. Philos Trans A Math Phys Eng Sci 371, 20130116.

BBC, (2010) Pakistan landlords 'diverted floodwater', BBC News website.

Beven, K. (2008) On doing better hydrological science. Hydrological Processes 22, 3549 3553.

Blue Planet, (2014) Submission to the Special Rapporteur on the Human Right to Safe Drinking Water and Sanitation Regarding Water Cut-offs in the City of Detroit, Michigan. The Blue Planet Project, Ottawa.

Boelens, R., Seemann, M. (2014) Forced Engagements: Water Security and Local Rights Formalization in Yanque, Colca Valley, Peru. Human Organzation 73, 1 - 12.

Briscoe, J. (2009) Water Security: Why It Matters and What to Do about It. Innovations 4, 3 28.

Brown, C. (2010) The End of Reliability. Journal of Water Resources Planning and Management 136, 143 - 145. 
Brown, C., Meeks, R., Ghile, Y., Hunu, K. (2013) Is water security necessary? An empirical analysis of the effects of climate hazards on national-level economic growth. Philosophical Transactions of the Royal Society - A 371: 20120416, 1 - 18.

Budds, J., McGranahan, G. (2003) Are the debates on water privatization missing the point? Experiences from Africa, Asia and Latin America. Environment and Urbanization 15, 87 - 113.

Calow, R., Ludi, E., Tucker, J., (2013) Achieving Water Security: Lessons from research in water supply, sanitation and hygiene in Ethiopia. Practical Action Publishing, London.

Calow, R., Mason, N., (2014) The real water crisis: inequality in a fast-changing world. Overseas Development Institute Framing Paper, London.

Castree, N., Adams, W.M., Barry, J., Brockington, D., Büscher, B., Corbera, E., Demeritt, D., Duffy, R., Felt, U., Neves, K., Newell, P., Pellizzoni, L., Rigby, K., Robbins, P., Robin, L., Rose, D.B., Ross, A., Schlosberg, D., Sörlin, S., West, P., Whitehead, M., Wynne, B. (2014) Changing the intellectual climate. Nature Climate Change 4, 763-768.

Clement, F., (2013) From Water Productivity to Water Security: A Paradigm Shift? , in: Lankford, B., Bakker, K., Zeitoun, M., Conway, D. (Eds.), Water Security: Principles, perspectives, practice. Routledge, London, pp. 148 - 165.

Coates, D., Loucks, D.P., Aerts, J., van't Klooster, S., (2012) Working under uncertainty and managing risk, in: UN-Water (Ed.), The United Nations World Water Development Report 4. UNESCO, Paris.

Collins, T.W. (2009) The production of unequal risk in hazardscapes: An explanatory frame applied to disaster at the US-Mexico border. Geoforum 40, 589-601.

Conway, D., (2013) Water Security in a Changing Climate, in: Lankford, B., Bakker, K., Zeitoun, M., Conway, D. (Eds.), Water Security: Principles, perspectives, practice. Routledge, London, pp. $80-100$.

Conway, D., Schipper, E.L.F. (2011) Adaptation to climate change in Africa: Challenges and opportunities identified from Ethiopia. Global Environmental Change 21, 227 - 237.

Cook, C., Bakker, K. (2012) Water Security: Debating an emerging paradigm. Global Environmental Change 22, 94 - 102.

Cooke, B., Kothari, U., (2001) Participation: The New Tyranny? Zed Books, London.

Delli-Priscoli, J. (2012) Reflections on the nexus of politics, ethics, religion and contemporary water resources decisions. Water Policy 14, 21 - 40.

Dent, D., Dalal-Clayton, B., (2014) Meeting the need for land resources information in the 21st century - or not: State-of-the Art Review, Environmental Governance Series No. 8, April 2014. International Institute for Environment and Development, London.

Dercon, S., (2012) Is Green Growth Good for the Poor?, Policy Research Working Paper 6231. The World Bank Development Research Group Environment and Energy Team \& Sustainable Development Network, Office of the Chief Economist, Washington, DC.

DFID, (2009) Water storage and hydropower: supporting growth, resilience and low carbon development: A DFID evidence-into-action paper, Policy Booklet. Department for International Development, London. 
DFID, (2015) DFID Smart Rules: Better Programme Delivery, Version V: effective 1st November 2015 until 31st March 2016. Department for International Development, London.

Doyle, M.W., Havlick, D.G. (2009) Infrastructure and the Environment. Annual Review of Environment and Resources 34, 349 - 373.

Falkenmark, M. (2013) Growing water scarcity in agriculture: future challenge to global water security. Philos Trans A Math Phys Eng Sci 371, 20120410.

Famiglietti, J.S. (2014) The global groundwater crisis. Nature Climate Change 4, 945 - 948.

Flyvbjerg, B. (2014) What You Should Know about Megaprojects and Why: An Overview. Project Management Journal 45, 6 - 19.

Foster, S., MacDonald, A. (2014) The 'water security' dialogue: why it needs to be better informed about groundwater. Hydrogeology Journal 22, 1489 - 1492.

García, L.E., Matthews, J.H., Rodriguez, D.J., Wijnen, M., DiFrancesco, K.N., Ray, P., (2014) Beyond Downscaling: A Bottom-up Approach to Climate Adaptation for Water Resources Management, AGWA Report 01. World Bank Group, Washington, DC.

Garrick, D., Hall, J.W. (2014) Water Security and Society: Risks, Metrics, and Pathways. Annual Review of Environment and Resources 39, 611 - 639.

Geels, F.W. (2014) Regime Resistance against Low-Carbon Transitions: Introducing Politics and Power into the Multi-Level Perspective. Theory, Culture \& Society 31, 21-40.

Gerlak, A.K., Wilder, M. (2012) Exploring the Textured Landscape of Water Insecurity and the Human Right to Water. Environment: Science and Policy for Sustainable Development 54, 4-17.

Grafton, R.Q., Pittock, J., Davis, R., Williams, J., Fu, G., Warburton, M., Udall, B., McKenzie, R., Yu, X., Che, N., Connell, D., Jiang, Q., Kompas, T., Lynch, A., Norris, R., Possingham, H., Quiggin, J. (2013) Global insights into water resources, climate change and governance. Nature Climate Change 3, 315 - 321.

Grey, D., (2012) A global framework for water security: why now? what? \& who?, Building the Water Agenda: Policy responses to water scarcity and shock. Chatham House, London, 9-10 July 2012.

Grey, D., Garrick, D., Blackmore, D., Kelman, J., Muller, M., Sadoff, C. (2013) Water security in one blue planet: twenty-first century policy challenges for science. Philosophical Transactions of the Royal Society - A A 371: 20120406.

Grey, D., Sadoff, C.W. (2007) Sink or Swim? Water security for growth and development. Water Policy 9, 545 - 571.

Gunderson, L. (1999) Resilience, Flexibility and Adaptive Management - Antidotes for Spurious Certitude? Ecology and Society 3, 7 - 18.

GWP, (2010) Water Security for Development: Insights from African Partnerships in Action. Global Water Partnership, Stockholm.

Hall, J., Borgomeo, E. (2013) Risk-based principles for defining and managing water security. Philosophical Transactions of the Royal Society - A 371: 20120407, 1 - 23. 
Hall, J.W., Grey, D., Garrick, D., Fung, F., Brown, C., Dadson, S.J., Sadoff, C.W. (2014) Coping with the curse of freshwater variability: Institutions, infrastructure, and information for adaptation. Science 346, 429 - 430.

Hallegatte, S. (2009) Strategies to adapt to an uncertain climate change. Global Environmental Change 19, 240 - 247.

Hanchett, S., Akhter, S., Hoque Khan, M. (2003) Water, sanitation and hygiene in Bagladeshi slums: an evaluation of the WaterAid-Bangladesh urban programme. Environment and Urbanization 15, 43 - 56.

Hatfield-Dodds, S., (2006) Water Strategies for Sustainable Development: What is required to ensure 'responsible growth'?, in: A response by Steve Hatflield Dodds to to 'Water for Growth and Development' - A theme document of the 4th World Water Forum by David Grey and Claudia Sadoff, W. (Ed.). Commonwealth Scientific and Industrial Research Organisation, Clayton, South Victoria.

Hawkins, S., (2015) The Challenges for Transboundary Aquifer Law and Governance, 'WaterWords' Blog of the London Water Research Group. King's College London and Water Security Research Centre of the University of East Anglia, London.

Hepworth, N., (2009) A progressive critique of IWRM in sub-Saharan Africa: beyond capacity towards self-determined regulatory personality, School of International Development. University of East Anglia, Norwich, UK.

Hepworth, N., Postigo, J.C., Güemes Delgado, B., (2010) Drop by drop: A case study of Peruvian asparagus and the impacts of the UK's water footprint. Progressio, in association with Centro Peruano De Estudios Sociales, and Water Witness International, London.

Hodgson, S., (2016) Exploring the concept of water tenure, Land and Water Discussion Paper 10. Food and Agriculture Organisation, Rome.

Hope, R., Rouse, M. (2013) Risks and responses to universal drinking water security. Philosophical Transactions of the Royal Society - A 371: 20120417.

Jepson, W. (2014) Measuring 'no-win' waterscapes: Experience-based scales and classification approaches to assess household water security in colonias on the US-Mexico border. Geoforum 51, 107-120.

Karimi, P., Bastiaanssen, W.G.M., Molden, D. (2013) Water Accounting Plus (WA+) - a water accounting procedure for complex river basins based on satellite measurements. Hydrology and Earth System Sciences 17, 2459-2472.

Kelly, P. (2014) Commentary - What to do when we run out of water. Nature Climate Change 4, 314 - 316.

Kemerink, J.S., Méndez, L.E., Ahlers, R., Wester, P., van der Zaag, P. (2013) The question of inclusion and representation in rural South Africa: challenging the concept of water user associations as a vehicle for transformation. Water Policy 15, 243.

Krishnan, J., George, A. (2009) Ecology and Equity in Rights to Land and Water: A Study in South-Eastern Palakkad in Kerala. Water Alternatives 2, 1 - 15.

Krueger, T., Maynard, C., Carr, G., Bruns, A., Mueller, E.N., Lane, S. (2016) A transdisciplinary account of water research. Wiley Interdisciplinary Reviews: Water. 
Kuklicke, C., Demeritt, D. (2016) Adaptive and risk-based approaches to climate chang and the management of uncertainty and institutional risk: The case of future flooding in England. Global Environmental Change 37, 56 - 68.

Lankford, B.A., (2013) Infrastructure hydromentalities: water sharing, water control and water (in)security, in: Lankford, B., Bakker, K., Zeitoun, M., Conway, D. (Eds.), Water Security: Principles, perspectives, practice. Routledge, London, pp. 256 - 272.

Lankford, B.A., Beale, T. (2007) Equilibrium and non-equilibrium theories of sustainable water resources management: dynamic river basin and irrigaiton behaviour in Tanzania. Global Environmental Change 17, 168 - 180.

Lautze, J., Manthrithilake, H. (2012) Water security: Old concepts, new package, what value? Natural Resources Forum 36, 76 - 87.

Lawford, R., Strauch, A., Toll, D., Fekete, B., Cripe, D. (2013) Earth observations for global water security. Current Opinion in Environmental Sustainability 5, 633 - 643.

Leach, M., Scoones, I., Stirling, A. (2010) Dynamic Sustainabilities. Technology, Environment, Social Justice. Earthscan, London.

Leb, C., Wouters, P., (2013) The Water Security Paradox and International Law, in: Lankford, B., Bakker, K., Zeitoun, M., Conway, D. (Eds.), Water Security: Principles, perspectives, practice. Routledge, London, pp. 26 - 45.

Linton, J. (2014) Modern water and its discontents: a history of hydrosocial renewal. Wiley Interdisciplinary Reviews: Water 1, 111-120.

Loftus, A. (2014) Water (in)security: securing the right to water. The Geographical Journal doi: $10.1111 /$ geoj.

Lundqvist, J., (2000) New Dimensions in Water Security: Water, society and ecosystem services in the 21st century, AGL/MISC/25/2000. Food and Agriculture Association of the United Nations, Land and Water Development Division, Rome.

LWEC, (2014) Climate impacts: taking action in the face of uncertainty, Policy and Practice Note No. 05. Living with Environmental Change Partnership, London.

Mason, N., (2013) Easy as 1, 2, 3? Political and Technical Considerations for Designing Water Security Indicators, in: Lankford, B., Bakker, K., Zeitoun, M., Conway, D. (Eds.), Water Security: Principles, perspectives, practice. Routledge, London, pp. 336 - 351.

Mason, N., Calow, R., (2012) Water security: from abstract concept to meaningful metrics: An initial overview of options, Working Paper 357. Overseas Development Institute, London.

Matthews, J., H., Wickel, B.A.J., Freeman, S. (2011) Converging Currents in Climate-Relevant Conservation: Water, Infrastructure, and Institutions. PLOS Biology 9, 1 - 4.

Matthews, N., Geheb, K., (2015) Hydropower Development in the Mekong Region: Political, Socio-economic and Environmental Perspectives. Routledge, London.

Matthews, N., Schmidt, J. (2014) False Promises: The contours, contexts and contestation of good water governance in Lao PDR and Alberta, Canada. International Journal of Water Governance 2. 
McCartney, M., Smakhtin, V., (2010) Water Storage in an Era of Climate Change: Addressing the Challenge of Increasing Rainfall Variability, Blue Paper, International Water Management Institute.

Merrey, D.J. (2009) Will Future Water Professionals Sink Under Received Wisdom or Swim to a New Paradigm? Irrigation and Drainage 58, S168 - S176.

Milly, P.C.D., Betancourt, J., Falkenmark, M., Hirsch, R.M., Kundzewicz, Z.W., Lettenmaier, D.P., Stouffer, R.J. (2008) Stationarity is Dead: Whither Water Management? Science 319, $573-574$.

Muller, M., Biswas, A., Martin-Hurtado, R., Tortajada, C. (2015) Built infrastructure is essential. Science 349, 585 - 586.

Muller, M., Schreiner, B., Smith, L., van Koppen, B., Hilmy, S., Aliber, M., Cousins, B., Tapela, B., van der Merwe-Botha, M., Karar, E., Pieterson, K., (2009) Water security in South Africa, Working Paper Series No. 12. Development Planning Division, Development Bank of Southern Africa, Midrand.

Mustafa, D. (2012) Water Resource Management in a Vulnerable World: The HydroHazardscapes of Climate Change. I.B. Tauris, London.

New, M., Lopez, A., Dessai, S., Wilby, R. (2007) Challenges in using probabilistic climate change information for impact assessments: an example from the water sector. Philos Trans A Math Phys Eng Sci 365, 2117-2131.

Nikolakis, W., Grafton, R.Q. (2014) Fairness and justice in indigenous water allocations: insights from Northern Australia. Water Policy.

Norman, E.S., Dunn, G., Bakker, K., Allen, D.M., Cavalcant de Alburquerque, R. (2013) Water Security Assessment: Integrating Governance and Freshwater Indicators. Water Resources Management 27, 535 - 551.

Norton, M.R. (2014) Water security: pipe dream or reality? A global perspective from the UK. Wiley Interdisciplinary Reviews: Water 1, 11-18.

OECD, (2013) Water security for better lives: A summary for policymakers. Organisation for Economic Cooperation and Development.

Osborn, T.J., Gosling, S., Wallace, C., Dorling, S., (2015) The Water Cycle in a Changing Climate, 7th World Water Forum. Faircount Media Group, London, pp. 14 - 19.

Oswald Spring, U., Brauch, H.G., (2014) Securitizing Water, in: Jägerskog, A., Swain, A., Öjendal, J. (Eds.), Water Security Volume 1: Water Security - Origin and Foundations. Sage, New York.

Pahl-Wostl, C., (2016) Water security, systemic risks and adaptive water governance and management, in: Pahl-Wostl, C., Bhaduri, A., Gupta, J. (Eds.), Handbook on Water Security. Edward Elgar Publishing Limited, Cheltenham.

Pahl-Wostl, C., Gupta, J., Bhaduri, A., (2016) Water security: a popular but contested concept, in: Pahl-Wostl, C., Bhaduri, A., Gupta, J. (Eds.), Handbook on Water Security. Edward Elgar Publishing Limited, Cheltenham. 
Pahl-Wostl, C., Palmer, M., Richards, K. (2013a) Enhancing water security for the benefits of humans and nature - the role of governance. Current Opinion in Environmental Sustainability 5, $676-684$.

Pahl-Wostl, C., Vörösmarty, C., Bhaduri, A., Bogardi, J., Rockström, J., Alcamo, J. (2013b) Towards a sustainable water future: shaping the next decade of global water research. Current Opinion in Environmental Sustainability 5, 708-714.

Palmer, M. (2010) Beyond infrastructure. Nature 467, 534 - 535.

Palmer, M.A., Liu, J., Matthews, J.H., Mumba, M., D'Odorico, P. (2015) Manage water in a green way. Science 349, 584 - 585.

Patrick, M.J., Syme, G.I., Horwitz, P. (2014) How reframing a water management issue across scales and levels impacts on perceptions of justice and injustice. Journal of Hydrology 519, $2475-2482$.

Pegram, G., Li, Y., Le Quesne, T., Speed, R., Li, J., Shen, F., (2013) River Basin Planning: Principles, Procedures and Approaches for Strategic Basin Planning, Part of a series on strategic water management. UNESCO, Paris.

Penrose, J.-P., (2012) Delivering Water Security - the challenges and opportunities for DFID, presentation given for Oxfod Water Security Network. Department for International Development, Oxford.

Petherick, A. (2012) Enumerating adaptation. Nature Climate Change 2, 228 - 229.

Poff, N.L., Brown, C.M., Grantham, T.E., Matthews, J.H., Palmer, M.A., Spence, C.M., Wilby, R.L., Haasnoot, M., Mendoza, G.F., Dominique, K.C., Baeza, A. (2015) Sustainable water management under future uncertainty with eco-engineering decision scaling. Nature Climate Change 6, 25-34.

Raadgever, G.T., Dieperink, C., Driessen, P.P.J., Smit, A.A.H., van Rijswick, H.F.M.W. (2011) Uncertainty management strategies: Lessons from the regional implementation of the Water Framework Directive in the Netherlands. Environmental Science \& Policy 14, 64-75.

RAE, (2010) Global Water Security - an engineering perspective. The Royal Academy of Engineering, London.

REACH, (2015) Country Diganostic Report, Ethiopia, REACH Working Paper 2. University of Oxford, Oxford.

Read, R., (2015) How to End Our Love Affair with Evidence, The Philosophers' Magazine online, Charlottesville.

Rovira, A., Polo, M.J., (2015) Current and future challenges in water resources management in Spain, Global Water Forum. UNESCO.

Sachs, J.D., Baillie, J.E.M., Sutherland, W.J., others, m. (2009) Biodiversity Conservation and the Millenium Development Goals. Science 28, 1502 - 1503.

Sadoff, C., Grey, D., (2008) Water Security: An Adaptation Imperative, Environment Matters at the World Bank: Climate Change and Adaptation. World Bank Group, Washington, DC.

Sadoff, C., Muller, M., (2009) Water Management, Water Security and Climate Change Adaptation: Early Impacts and Essential Responses, TEC Background Paper No. 14. Global Water Partnership Technical Committee. 
Sadoff, C.W., Grey, D. (2002) Beyond the river: the benefits of cooperation on international rivers. Water Policy 4, 389-403.

Sadoff, C.W., Hall, J.W., Grey, D., Aerts, J.C.J.H., Ait-Kadi, M., Brown, C., Cox, A., Dadson, S., Garrick, D., Kelman, J., McCornick, P., Ringler, C., Rosengrant, M., Whittington, D., Wiberg, D., (2015) Securing Water, Sustaining Growth: Report of the GWP/OECD Task Force on Water Security and Sustainable Growth. University of Oxford, Oxford.

Salzberg, A., (2009) International Water Issues: An overview and the U.S. Response. U.S. Department of State, Presentation given to the Farm Foundation.

Savenije, H.H.G., van der Zaag, P. (2008) Integrated water resources management: Concepts and issues. Physics and Chemistry of the Earth 33, 290 - 297.

Sayers, P., Galloway, G., Penning-Rowsell, E., Yuanyuan, L., Fuxin, S., Yiwei, C., Kang, W., Le Quesne, T., Wang, L., Guan, Y. (2014) Strategic flood management: ten 'golden rules' to guide a sound approach. International Journal of River Basin Management, 1-15.

Schmidt, J.J., (2012) Scarce or insecure? The right to water and the changing ethics of global water governance, in: Sultana, F., Loftus, A. (Eds.), The right to water: politics, governance and social struggles. Routledge, London, pp. 94 - 109.

Scott, C.A., Meza, F.J., Varady, R.G., Tiessen, H., McEvoy, J., Garfin, G.M., Wilder, M., Farfán, L.M., Pablos, N.P., Montaña, E. (2013) Water Security and Adaptive Management in the Arid Americas. Annals of the Association of American Geographers 103, 280-289.

Scott, C.A., Pierce, S.A., Pasqualeti, M.J., Jones, A.L., Montz, B.E., Hoover, J.H. (2011) Policy and institutional dimensions of the water-energy nexus. Energy Policy 39, 6622 - 6630.

Scott, C.A., Varady, R.G., Meza, F., Montaña, E., de Raga, G., Luckman, B., Martius, C. (2012) Science-policy dialogues for water security: addressing vulnerability and adaptation to global change in the arid Americas. Environment 54, 30 - 42.

Seekell, D.A., D'Odorico, P., Pace, M.L. (2011) Virtual water transfers unlikely to redress inequality in global water use. Environmental Research Letters 6, doi:10.1088/17489326/1086/1082/024017.

Selby, J. (2013) Cooperation, Domination and Colonisation: The Israeli-Palestinian Joint Water Committee. Water Alternatives 6, 1 - 24.

Sigel, K., Klauer, B., Pahl-Wostl, C. (2010) Conceptualising uncertainty in environmental decision-making: The example of the EU Water Framework Directive. Ecological Economics 69, 502 - 510.

Simons, G.W.H., Bastiaanssen, W.G.M., Immerzeel, W.W. (2015) Water reuse in river basins with multiple users: A literature review. Journal of Hydrology 522, 558-571.

Singh, R., Wagener, T., Crane, R., Mann, M.E., Ning, L. (2014) A vulnerability driven approach to identify adverse climate and land use change combinations for critical hydrologic indicator thresholds: Application to a watershed in Pennsylvania, USA. Water Resources Research 50, 3409 - 3427.

Steward-Koster, B., Bunn, S.E., (2016) The ecology of water security, in: Pahl-Wostl, C., Bhaduri, A., Gupta, J. (Eds.), Handbook on Water Security. Edward Elgar Publishing Limited, Cheltenham. 
Stirling, A. (2010) Keep it complex: When knowledge is uncertain, experts should avoid pressures to simplify their advice. Nature 468, 1029 - 1031.

Stirling, A., Leach, M., Mehta, L., Scoones, I., Smith, A., Stagl, S., Thompson, J., (2007) Empowering Designs: towards more progressive appraisal of sustainability, STEPS Working Paper 3. STEPS Centre, University of Sussex, Brighton:.

Tarlock, D., Wouters, P. (2010) Reframing the Water Security Dialogue. The Journal of Water Law 20, 53 - 60.

Taylor, R.G., Scanlon, B., Döll, P., Rodell, M., van Beek, R., Wada, Y., Longuevergne, L., Leblanc, M., Famiglietti, J.S., Edmunds, M., Lonikow, L., Green, T.R., Chen, J., Taniguchi, M., Bierkens, M.F.P., MacDonald, A., Fan, Y., Maxwell, R.M., Yechieli, Y., Gurdak, J.J., Allen, D.M., Shamsudduha, M., Hiscock, K., Yeh, P.J.-F., Holman, I., Treidel, H. (2013) Groundwater and climate change. Nature Climate Change 3, 322 - 329.

The Economist, (2009) Let it rain: how rainfall can affect economic growth, The Economist, London.

The Hague Ministerial Declaration, (2000) Ministerial Declaration of The Hague on Water Security in the 21st Century. Declaration made at the second World Water Forum, 17-22 March, The Hague.

Tickner, D., Acreman, M., (2013) Water security for ecosystems, ecosystems for water security, in: Lankford, B., Bakker, K., Zeitoun, M., Conway, D. (Eds.), Water Security: Principles, perspectives, practice. Routledge, London, pp. 130 - 147.

UN ILC, (2008) Draft articles on the law of transboundary aquifers, Report of the International Law Commission, Sixtieth session, A/63/10. International Law Commission.

UN-Water, (2012a) Managing Water under Uncertainty and Risk, The United Nations World Water Development Report 4. UNESCO, Paris.

UN-Water, (2012b) Water Security \& the Global Water Agenda, A UN-Water Analytical Brief. United Nations University Institute for Water, Environment \& Health, Hamilton.

UNEP, (2008) Vital Water Graphics: Water storage capacity for selected countries, UNEP/GRID-ARENDAL. United Nations Environment Program.

van Aalst, M., Hellmuth, M., Ponzi, D., (2007) Come Rain or Shine: Integrating Climate Risk Management into African Development Bank Operations, Working Paper No 89. African Development Bank, Tunis.

van Beek, E., Lincklaen Arriens, W., (2014) Water Security: Putting the Concept into Practice, TEC Background Paper No. 20. Global Water Partnership Technical Committee (TEC), Stockholm.

van der Zaag, P., Gupta, J. (2008) Scale issues in the governance of water storage projects. Water Resources Research 44, n/a-n/a.

Varis, O. (2014) Curb vast water use in central Asia. Nature 514, 27 - 29.

Venot, J.P., Clement, F. (2013) Justice in development? An analysis of water interventions in the rural South. Natural Resources Forum 37, 19 - 30. 
Vera Delgado, J.R., (2011) The Ethno-politics of Water Security: Contestations of ethnicity and gender in strategies to control water in the Andes of Peru, PhD Thesis completed at the Wageningen School of Social Sciences. Wageningen University, Wageningen.

Verweij, M., Thompson, M., (2006) Clumsy Solutions for a Complex World. Palgrave MacMillan.

Vörösmarty, C.J., Mclntyre, P.B., Gessmer, M.O., Dudgeon, D., Prusevich, A., Green, P., Glidden, S., Bunn, S.E., Sullivan, C.A., Reidy Liermann, C., Davies, P.M. (2010) Global threats to human water security and river biodiversity. Nature 467, 555 - 561.

Vörösmarty, C.J., Pahl-Wostl, C., Bunn, S.E., Lawford, R. (2013) Global water, the anthropocene and the transformation of a science. Current Opinion in Environmental Sustainability 5, $539-550$.

Warner, J., Johnson, C.L. (2007) 'Virtual Water' - Real People: Useful Concept or Prescriptive Tool? Water International 32, 63 - 77.

Warner, J., Wester, P., Bolding, A. (2008) Going With the Flow: River Basins as the Natural Units for Water Management? Water Policy 10, 121 - 138.

WaterAid, (2012) Water Security Framework. Water Aid, London.

WEF (2011) Water Security: The Water-Food-Energy-Climate Nexus. Island Press, Washington.

Whittington, D., Hannemann, M., Sadoff, C., Jeuland, M. (2009) The Challenge of Improving Water and Sanitation Services in Less Developed Countries. Foundations and Trends in Microeconomics 4, 469 - 609.

World Bank, (2004) Towards a Water-Secure Kenya: Water Resources Sector Memorandum, Water and Urban I - Africa Region, Report No. 28398-KE. The World Bank, .

World Bank, (2006) Ethiopia: Managing Water Resources to Maximize Sustainable Growth, Country Water Resources Assistance Strategy. The World Bank, Washington, DC.

World Bank, (2015) Action Plan: Improving the Management of Safeguards and Resettlement Practices and Outcomes. International Bank for Reconstruction and Development, Washington.

WRG, (2010) Charting Our Water Future: Economic frameworks to inform decision-making. 'Water Resources Group': The Barilla Group, The Coca-Cola Company, The International Finance Corporation, McKinsey \& Company, Nestlé S.A., New Holland Agriculture, SABMiller plc,Standard Chartered Bank, and Syngenta AG. (a.k.a. 'the McKinsey Report').

WRG, (2014) Building Partnerships for Water Security - for People, Growth, and the Environment. 2014 Annual Report of the 2030 Water Resources Group, Washington, DC.

WWC-OECD, (2015) Water: Fit to Finance? Catalyzing National Growth Through Investment in Water Security, Report of the High Level Panel on Financing Infrastructure for a WaterSecure World. World Water Council and the Organisation for Economic Co-peration and Development, Marseille.

WWDR (2009) The United Nations World Water Development Report 3: Water in a Changing World. UNESCO/Earthscan, Paris, London. 
WWF, (2014) Living Planet Reprot 2014 - Species and spaces, people and places. Worldwide Fund for Nature, Gland.

Zeitoun, M. (2011) The Global Web of National Water Security. Global Policy 2, 286 - 296.

Zeitoun, M., Cascão, A., Warner, J., Mirumachi, N., Matthews, N., Farnum, R., Menga, F. (in press) Transboundary water interaction III: Contesting hegemonic arrangements. International Environmental Agreements.

Zeitoun, M., Lankford, B., Bakker, K., Conway, D., (2013) Introduction: A Battle of Ideas for Water Security, in: Lankford, B., Bakker, K., Zeitoun, M., Conway, D. (Eds.), Water Security: Principles, perspectives, practice. Routledge, London.

Zeitoun, M., McLaughlin, K., (2013) Basin Justice: Using social justice to address gaps in river basin management, in: Sikor, T. (Ed.), Just Ecosystem Management. Routledge, Abingdon and New York.

Zwarteveen, M., Z., Boelens, R. (2014) Defining, researching and struggling for water justice: some conceptual building blocs for research and action. Water International 39, 143 - 158. 